\title{
Controlling Shareholder and Tax Avoidance: Family Ownership and Corporate Governance
}

\author{
Masripah, Vera Diyanty, Debby Fitriasari \\ Universitas Indonesia, Depok
}

\begin{tabular}{l} 
A R T I C L E I N F O \\
\hline Keywords: \\
controlling shareholder; \\
commissioner; \\
audit committee; \\
external audit; \\
tax avoidance
\end{tabular}

Corresponding author: masripah.ipah@gmail.com

\section{A B S T R A C T}

The objective of this study is to analyze the entrenchment effect of controlling shareholder on tax avoidance, as well as looking at the role of family ownership, commissioner effectiveness, audit committee effectiveness and external audit quality. This research is a quantitative research using fixed effects model. Sample of this research is 70 firms with an observation period of 2010 until 2013. This study finds that the entrenchment effect of controlling shareholder has negative effect on tax avoidance. Other test results show that when a family is the controlling shareholder, entrenchment effect of controlling shareholder do not affect on tax avoidance. Board of commissioner and committee effectiveness proved to weaken the relationship between entrenchment effect of controlling shareholder and tax avoidance. However, the role of external quality audit does not prove to weaken the relationship between the entrenchment effect of controlling shareholder and tax avoidance.

(C) 2016 IRJBS, All rights reserved.

\section{INTRODUCTION}

The ownership structure of companies in Indonesia tends to be concentrated. Those companies are controlled by few shareholders, hereinafter referred to as controlling shareholders (Claessens, Djankov, \& Lang, 2000; Siregar, 2007; Diyanty, 2012). Concentrated ownership canreduce the agency problem between shareholders and management. However, it will create a conflict of interest between controlling shareholder and non-controlling shareholder due to separation of control and cash flow rights through interenterprise pyramid structure or cross-holdings.

According to La Porta, Silanes, and Shleifer (1999), control right is the percentage of voting rights of shareholders to participate in policy decisions of the company, while the cash flow right is shareholders' financial claims against the company based on the percentage of investment. Shareholders' control right in the company should be represented by the shareholders' cash flow 
right arising from the actual investment. However, the influence of the pyramid structure and participation in the management make control right and corresponding economic exposure exactly not the same. This is what causes the controlling shareholder to have control right over the company in excess of their investment stake. Differences in control right and cash flow right encourage controlling shareholder expropriate ${ }^{1}$ by arranging transactions in a company that can be detrimental to the minority shareholders. This is known as the negative effect of entrenchment ${ }^{2}$ behavior of controlling shareholder.

Hanlon and Heitzman (2010) stated that tax avoidance can be seen as an indication of an agency problem. There are several research about agency conflict which arose due to separation of ownership and control. McGuire, Wang, and Wilson (2011) examined the relationship of agency conflicts in a dual-class ownership structure with the level of firms' tax avoidance. They found that management who has control rightsmore than their cash flow right will have a negative correlation with tax avoidance. These findings are consistent with the "quite life" theory, which argues that management will avoid both expropriation and legal activities that could increase firm value if either activity requires costly efforts. Badertscher, Katz, and Rego (2013) examined variation in the separation of ownership and control influence on the tax practices of private firms with different ownership structures. They stated that firms with more concentrated ownership and control will reduce tax avoidance due to its risk which can impose significant costs on the firm and will induce risk-averse behavior from the managers.

Improving previous research by McGuire et al. (2011) and Badertscher et al. (2013), this study examined the entrenchment effect of controlling shareholder for public companies in Indonesia (especially manufacturing) which is associated with tax avoidance. According to La Porta et al. (1999), controlling shareholder with control right more than cash flow right can be involved in the management's decision making regarding policies and operations of the firm. Thereby controlling shareholders can manage to regulate corporate transactions, including tax evasions and tax benefits transferred to another firm belonging to the controlling shareholders without having to share it with the minority shareholders of the initial company.

Most of public companies in Indonesia are owned by family as the main controlling shareholder (Siregar, 2007; Diyanty, 2012). Sari (2010) provides a preliminary description of the firm in Indonesia that family owned companiesare more likely to commit aggressive tax planning than non-family firms.This happens because the possibility of the tax savings for the company in Indonesia is greater than the likelihood of getting a fine from the tax office and the possibility of decreasing stock prices due to the firm's negative image. Therefore, tax avoidance committed by the controlling shareholder is likely to increase if the controlling shareholder is an individual or a family. This dominance of controlling family shareholder will trigger higher agency conflicts between controlling family shareholder andnon-family shareholder regarding the firm's tax planning.

Friese, Link, and Mayer (2006) state that tax planning occurrence in companies depends on the dynamics of corporate governance. Indonesian Institute for Corporate Governance (IICG) defines corporate governance as the processes and structures that are applied in running the firm

\footnotetext{
${ }^{1}$ The definition of expropriation according to Haryono (2008) that measures maximize the benefits received by one party at the expense of the other party. Other party in this study is minority shareholders.

${ }^{2}$ Entrenchmentis the ability of shareholders to control management decisions in determining the policies and operation of the company (Fan \& Wong, 2002)
} 
with a primary objective to increase shareholder value over the long term by taking into account the interests of stakeholders. The crucial aspect of a successful implementation of corporate governance is a full commitment of Board of Commissioners, the existence of an effective audit committee, and transparency of firm's financial statements to public (Effendi, 2009).

Previous empirical studies have not been performed comprehensively to test the entrenchment effect of controlling shareholders, the role of family ownership and the effectiveness of corporate governance mechanism against tax avoidance. Therefore, this study is important to be performed in Indonesia to see the effect of separation of cash flow rights and control rights that may lead to expropriation by controlling shareholders against tax avoidance, and examine the role of family ownership and corporate governance mechanism as measured by Board of Commissioners effectiveness, audit committee effectiveness, and external audit quality.

\section{Preliminary Research}

The separation of ownership and control have created the agency problem. McGuire, Wang, and Wilson (2011) conducted a study in dual-class firms. The results showed that the magnitude of the difference between control rights and cashflow rights of management is negatively related to the firms' tax avoidance, despite the benefits of tax avoidance. Tax avoidance can lead to greater tax savings which potentially reduce the tax expense on the financial statements and increase firms' cash flow. The reason of negative relationship is because even though the management has high control rights, they have limited cash flow rights which give them a low incentive to perform tax avoidance. Hence, the tax savings obtained are also limited according to cash flow rights of the management.

A research by McGuire et al. (2011) supports the "quiet life" theory which states that entrenched managers will avoid costly efforts which in this case are associated with tax planning activities. In addition, entrenched managers can act as they pleased without having to worry about losing their position in the firm besides having little or no pressure from investors to improve the firm's earnings. Therefore managers will be less involved in tax avoidance. Badertscher et al. (2013) also found that management in a highly concentrated ownership and control firm tends to have less involvement in tax avoidance, compared to management in a less concentrated ownership and control firm. Those findings align with Fama and Jensen (1983) argument that when equity ownership and decision making are concentrated to few decision makers, management will be more risk averse and less likely to invest in a risky project.

Tax avoidance is one risk activity that has potential consequences for government, creditors, managers, and the shareholders (e.g., fees paid to tax experts, the time spent for the resolution of tax audits, fines reputation, and fines are paid to the tax authorities) (Hanlon \& Heitzman, 2010). This leads to more risk averse entrenched managers which will avoid costly efforts on risky tax planning. Hence, costly tax planning activities will be considered by managers as well as controlling shareholders.

The greater control rights of controlling shareholders will increase the entrenchment effect that encourages the controlling shareholders' expropriation getting worse. This is because according to La Porta et al. (1999) when pyramid structure or cross-holding with control rights are high, the controlling shareholders gain disproportionate force against their cash flow rights. In these conditions, the controlling shareholders can influence manager's decision to commit tax avoidance, even when controlling shareholders may enjoy such benefits alone. For example, firm transfer pricing to a new firm formed by the controlling shareholders in tax-free areas as 
a means to hide the firm's earnings and an attempt of tax avoidance. Thus, controlling shareholders can enjoy the benefits of its own through its subsidiaries, while the cost of tax avoidance will be borne by the company and its shareholders, including the controlling shareholders but only limited to its cash flow rights. According to Lo, Wong, and Firth (2010), corporate income tax rate is a factor to make transfer pricing decisions. Therefore, the first hypothesis in this study is:

H1: an entrenched controlling shareholder has a positive effect on tax avoidance activities.

Public firm in Indonesia is largely controlled by a single shareholder who among these companies is family and small firm (Claessens et al., 2000; Siregar, 2007; Diyanty, 2012). In relative terms, a family-owned firm with high ownership is more likely to behave like an individual (Hanlon \& Heitzman, 2010). The behavior is due to the separation of ownership and control that will ultimately lead to the agency conflict related to personal interests of controlling shareholders at the expense of the rights of minority shareholders.

According to Desai and Dharmapala (2006), family owned companies are willing to forgo the benefits of tax savings and ignore tax avoidance rather than incur potential fines and expose the firm to the risk of a bad reputation from audit examination. According to a research conducted by Chen, Chen, Cheng, and Shevlin (2010) for the period 1996 to 2000 , it proved that family firms tend to have higher levels of tax aggressiveness (an extreme form of tax avoidance) than non-family firms. However, all prior studies are different from the results of Sari's study (2010) conducted in Indonesia. Sari (2010) provides a preliminary picture that family-owned firms in Indonesia are likely to be more aggressive in taxation than non-family-owned firms. The possibility of the occurrence of this phenomenon is because the benefits to be received by the controlling shareholders are greater in number than the loss that will be received as a result of the possibility of tax fines, sliding stock prices and the decline in the reputation of the firms. Thus the second hypothesis in this study is:

H2: family ownership as controlling shareholder strengthensthe effect of entrenched controlling shareholders in tax avoidance.

Board of Commissioners (BoCs) as internal control mechanisms of corporate governance is basically emphasized in order to reduce agency conflict, so as to limit and exercise effective control on the actions taken by a manager or a majority shareholder to expropriate. The existence of BoCs effectiveness is expected to control activities undertaken by managers in the act of tax avoidance. In addition, BoCs who carry out their duties and responsibilities can effectively provide protection and guarantee equal treatment for all shareholder classes.

Lanis and Richardson (2011) show that a higher number of independent board members can reduce the company's aggressiveness on tax avoidanceby improving the corporate governance. The board should oversee managers to ensure that managers actions in running the company are in accordance with all stakeholders and society as a whole.

Board of Commissioners can improve protection of minority shareholders when they perform effectively. They will be able to monitor, restrict and carry out effective controls on the managers or majority shareholders' expropriation act to avoid tax. Thus, hypothesis in this study is as follows:

H3: BoCs effectiveness weakens the effect of entrenched controlling shareholders on tax avoidance.

Richardson, Taylor, and Lanis (2013) examined the independence of internal audit committee with tax aggressiveness which indicates that the independence of internal audit committee has 
an important role in minimizing the possibility of tax aggressiveness in the firms. Independent audit committee is thought to enhance the firm's reputation through more effective monitoring on managers, the potential damage to reputation in terms of financial misstatement (or taxes) in the firm's annual report. Accordingly, audit committee is expected to assess the reasonableness of methods and assumptions used in the preparation of accounting and tax-related information adopted by managers. Therefore, hypothesis in this study will be stated as:

H4: audit committee effectiveness weakens the effect of entrenched controlling shareholders on tax avoidance.

Francis (2004) studied the audit quality for listed firms because of the separation between owners and managers. As a consequence, there is a need for an independent auditor to promote good corporate governance particularly in term of monitoring activities. Baker and Owsen (2002) also argued that the auditor has a role in improving control of the firm which will be beneficial to all stakeholders and the public in general. This is because external auditors consider good corporate governance when planning the audit. On the other hand, the research related to the relationship between tax aggressiveness (an extreme form of tax avoidance) and external audit quality already exists which previously examined, that Big 4 accounting firm can be helpful in reducing tax aggressiveness by firms (client) through increased monitoring and a higher quality audits (Richardson et al., 2013). Thus the next hypothesis that can be proposed is:

H5: external audit quality weakens the effect of entrenched controlling shareholders on tax avoidance.

\section{METHODS}

Data Source and Sample Selection

This study uses secondary data such as financial data and annual reports obtained from Eikon Thomson Reuters in Data Center Economic and Business-Faculty of Economic University of Indonesia (PDEB-UI), BEI website or on the company website. Data ownership structure is obtained by tracking corporate ultimate ownership from Data Center Business Indonesia and Ministry of Law and Justice. Sample selection criteria are: (i) public companies in manufacturing industries which are listed on Indonesia Stock Exchange from 2010 until 2013; (ii) company with score of ETR and CETR more than one; (iii) except owners of ASTINDO ${ }^{3}$; (iv) company with positive income; (v) company with complete data needed in certain year.

\section{Empirical Model and Research Variables}

This study used two equations model to test five hypotheses of the study. The first equation model was used to test the magnitude of controlling shareholder entrenchment effect in reducing tax avoidance action, as the hypothesis 1. The second equation model was created to test the role of family ownership, BoCs effectiveness, audit committee effectiveness, and external quality audit in relation entrenchment effect controlling shareholders with tax avoidance, as stated in hypothesis $2,3,4$, and 5 respectively. Here are two models of the equation:

\section{Model 1}

$$
\begin{aligned}
\operatorname{TaxAvd}_{\mathrm{it}}= & \alpha+\beta_{1} \mathrm{WEDGE}_{\mathrm{it}}+\beta_{2} \mathrm{ROA}_{\mathrm{it}} \\
& +\beta_{3} \mathrm{LEV}_{\mathrm{it}}+\beta_{4} \mathrm{PPE}_{\mathrm{it}}+\beta_{5} \mathrm{MB}_{\mathrm{it}}+\varepsilon_{\mathrm{it}}
\end{aligned}
$$

\section{Model 2}

$$
\begin{aligned}
\operatorname{TaxAvd}_{\mathrm{it}}= & \alpha+\beta_{1} \text { WEDGE }_{\mathrm{it}}+\beta_{2} \text { FAMILY }_{\mathrm{it}} \\
& +\beta_{3} \mathrm{EDK}_{\mathrm{it}}+\beta_{4} \text { EKA }_{\mathrm{it}}+\beta_{5} \mathrm{KAE}_{\mathrm{it}} \\
& +\beta_{6} \text { WEDGE }_{\mathrm{it}}^{*} \text { FAMILY }_{\mathrm{it}}
\end{aligned}
$$

${ }^{3}$ Controlling shareholders was not categorized as foreign but Indonesia by Kim (2003) in Diyanty (2012) later called ASTINDO 


$$
\begin{aligned}
& +\beta_{7} \mathrm{WEDGE}_{\mathrm{it}}{ }^{*} \mathrm{EDK}_{\mathrm{it}}+\beta_{8} \mathrm{WEDGE}_{\mathrm{it}}{ }^{*} \mathrm{EKA}_{\mathrm{it}} \\
& +\beta_{9} \mathrm{WEDGE}_{\mathrm{it}} \mathrm{KAE}_{\mathrm{it}}+\beta_{10} \mathrm{ROA}_{\mathrm{it}} \\
& +\beta_{11} \mathrm{LEV}_{\mathrm{it}}+\beta_{12} \mathrm{PPE}_{\mathrm{it}}+\beta_{13} \mathrm{MB}_{\mathrm{it}} \\
& +\varepsilon_{\mathrm{it}}
\end{aligned}
$$

Whereas, $\operatorname{Tax} \mathrm{Avd}_{\mathrm{it}}=$ tax avoidance is measured using ETR and CETR; WEDGE = difference between control rights and cash flowrights; FAMILY $_{\mathrm{it}}=$ dummy variable, has score 1 if firm $\mathrm{i}$ in year $\mathrm{t}$ which includes family ownership and score 0 if on the contrary; EDK BOCs effectiveness; EKA= audit committee effectiveness; $\mathrm{KAE}=$ external quality audit; WEDGE *FAMILY = interaction variables WEDGE and FAMILY; WEDGE *EDK= interaction variables WEDGE and EDK; WEDGE *EKA = interaction variables WEDGE and EKA; WEDGE * KAE $=$ interaction variables WEDGE and $\mathrm{KAE} ; \mathrm{LEV}_{\mathrm{it}}=$ ratio of long term debt to total asset; $\mathrm{PPE}_{\mathrm{it}}=$ value of property, plant, and equipmentfor companyi, year $\mathrm{t}$, is divided to value of total asset (t-1); $\mathrm{MB}_{\mathrm{it}}=$ market-to-book ratiofor companyi, in beginning of year $t$, is calculated with divide market value of equity to book value of equity.

\section{Dependent Variable}

The dependent variable in this study is tax avoidance. This study uses the measurement of tax avoidance as in the research by McGuire et al. (2011). There are two proxies used in research by McGuire et al. (2011) to measure tax avoidance, namely cash effective tax rates and effective tax rates. Nevertheless, this research only used the effective tax rates for the measurements. This is because of the bias in calculating cash effective tax rates. The tax rate presented in the cash flow statement does not only represent the corporate income tax, but also other taxes such as customs tax. However, as a replacement measuring of cash effective tax rates, and with a view to strengthening the model in predicting research findings, this study uses current effective tax rates as the measurement.

The ETR and CETR in this study have a value with a range of $0-1$ as used in the research by Chen et al. (2010) and Sari (2010). The companies which have a value of ETR and CETR more than one will be excluded from the sample. A negative value of ETR and CETR are converted to zero value in line with a research by Taylor and Richardson (2014) to avoid problems in the processing of estimate model. The purpose of this selection is to exclude the outliers which will not be comparable to other companies.

\section{Independent Variable}

Wedge is used as a proxy to measure independent variable in this study, the entrenchment effect of controlling shareholders in the form of expropriation incentive to non-controlling shareholders. Wedge value can be calculated by separating shareholder's control rights and cash flow rights through ownership structure of pyramid or cross-ownership.

\section{Variable Moderation \\ Family Ownership}

Family ownership in this study follows the definition used in the study of Diyanty (2012) which is the ultimate controlling shareholder of an ownership chain. This information is obtained by tracing the shareholders who belong to the same family. Family ownership is measured using a dummy value. 1 is given when the ultimate controlling shareholder is an individual or a family group. Otherwise, the dummy value is 0 .

\section{BoCs Effectiveness and Audit Committee Effectiveness}

Measurement of BoCs effectiveness and audit committee effectiveness in this study will refer to the research by Hermanwan (2009) which looks at the characteristics (independence, activity, the number of members, and competence) owned by the commissioners and the audit committees. There are 17 questions to score the effectiveness of oversight function of the audit committee which will consist of two possible answers (good and poor) and three possible answers (good, fair, and poor). The Answer "good" rated will be rated 
3 , "fair" rated 2, and the "poor" is given a value of 1 . On a question that the answer can not be obtained from the company's annual report, it will be rated poor response (value 1). In this study, the score of BoCs effectiveness and audit committee effectiveness is measured using a dummy variable to see the total value of the whole question. This methodology is a replication of the research method by Hermanwan (2009).

\section{External Audit Quality}

Companies which are audited by Big4 Accounting Firms ${ }^{4}$ can have a major influence on the level of tax avoidance actions by the company. Richardson, Taylor, and Lanis (2013) state that companies audited by Big 4 Accounting Firms should be able to reduce tax avoidance action compared to companies audited by Non-Big 4 Accounting Firm. In this research, the quality audit is proxied by the size of the public accounting firm, which is rated 1 if the company's annual report is audited by Big 4 and rated 0 if the company's annual report is audited by a firm other than Big4 .

\section{Variables Control}

This research model also included a few control variables, namely: return on assets (ROA); leverage; property, plant, and equipment (PPE); and the market-to-book ratio (MB).

\section{Data Processing and Hypothesis Testing}

Testing hypothesis of this study will be done by regression analysis method using the balanced panel data model.

\section{RESULTS AND DISCUSSION}

\section{Descriptive Statistics}

The population of companies included in this study is companies which are listed on the Indonesia Stock Exchange from 2010 until 2013. Total samples in this study consist of 70 companies which made it into 280 firm-year observations (see Table 1 in Appendix). This study used two proxies to measure the level of tax avoidance action, namely ETR (effective tax rate) and CETR (effective current tax rate). Based on Table 2 in Appendix, the average value of ETR is $25 \%$ and the average value of CETR is $22 \%$. The percentage shows that the average manufacturing company in Indonesia has a value of effective tax rate which is only slightly different from statutory tax rate.

The maximum and minimum value of wedge (WEDGE) in the sample are 0.40 and 0 . This value indicates the spread of the difference between control rights and cash-flow rights of shareholders in the sample. Percentage of control rights and cash flow rights can be traced through a chain of shareholders ownership to find out the controlling shareholder and categorize as family or non-family owned companies. The sample consists of 128 or $46 \%$ of family-owned companies and 152 or $54 \%$ non-family owned companies (see Table 2 in Appendix).

The average value of BoCs effectiveness and audit committee effectiveness in the sample are $68 \%$ and $71 \%$ respectively (see Table 2 in Appendix). These percentage shows that the overall function of BoCs and audit committee in the samples have a quite effective internal control mechanism of corporate governance. The average of the external audit quality index in the sample is $44 \%$ (see Table 2 in Appendix) which shows that more than half of the sample firms are audited by non-Big 4 accounting firm.

\section{The Relationship between Entrenched Controlling Shareholders and Tax Avoidance}

The result of the tests shows that the discrepancy between control right and cash flow right of controlling shareholders significantly affects the

\footnotetext{
${ }^{4}$ The four largest accounting firms in the world, such as PricewaterhouseCoopers (PwC), Deloitte Touche Tohmatsu Limited, Ernst \& Young (E\&Y), and Klynveld Peat Marwick Goerdeler (KPMG)
} 
ETR and CETR in a positive direction (see Table 3 in Appendix). It means that entrenched controlling shareholder has a negative effect on corporate tax avoidance actions. Thus, the first hypothesis in this study was not proven. However, this study turned out to support the research results in McGuire et al. (2011) which shows that difference between control rights and cash-flow rights affect the value of effective tax rates were higher, the management has more control rights used to reduce corporate tax avoidance. In accordance with the quiet life theory stated by McGuire et al. (2011), this study hypothesizes that entrenched controlling shareholders may participate in management to avoid businesses spend costly though tax avoidance is legal activities. This is because controlling shareholders who have cash flow rights is limited and there are costs to be incurred managers and company in tax planning such as tax avoidance. According to research Badertcher et al. (2013), a negative relationship can also be caused by ownership and corporate decision makers concentrated in just a handful of certain parties (controlling shareholder) in making decisions. Therefore, the controlling shareholder will become risk averse and may influence management to reduce investment in the project at risk including reducing tax avoidance.

Based on descriptive statistics, controlling shareholder's value wedge in company sample relatively small. The possibility is not acceptable empirically for the first hypothesis in this study due to difference between control rights with cash flow rights of controlling shareholders is lower in sample companies, so that controlling shareholder is not interested in doing acts of tax avoidance considering cash flow rights is limited and the cost to do acts of tax avoidance.

\section{Analysis Relationship between Family Ownership as Controlling Shareholders and Tax Avoidance}

Hypothesis 2 (H2) argues that family ownership as controlling shareholder strengthens the entrenchment effect of controlling shareholders on tax avoidance. Results of this study indicate that the relationship has a positive effect but not a significant value (see Table 4 in Appendix). Thus, the second hypothesis in this study is not accepted. The family ownership does not have a negative effect on tax avoidance when family ownership was moderating the entrenchment effect of controlling shareholder on tax avoidance. Family as a controlling shareholder reduces the aggressiveness of tax avoidance possibility due to the low value of wedge in the sample. Moreover, this phenomenon is believed to have occurred due to the possibility of private benefits received by the controlling shareholder which is greater by tunneling profits to parent company rather than tax savings. Lo et al. (2010) find that ownership concentration in Chinese government has influence in the decision of transfer pricing. Therefore a company is willing to ignore tax savings to tunnel profits to the parent company. However, the study of Lo et al. (2010) does not provide evidence which shows the incentives for shareholders to consider tax avoidance or tunneling when they decide to make a transfer pricing.

\section{Analysis of BoCs Effectiveness Influence on Controlling Shareholders and Tax Avoidance Relationship}

Hypothesis 3 (H3) states that BoCs effectiveness weakens the influence of controlling shareholder entrenchment effect against tax avoidance. The result showed a positive effect and significant correlation (see Table 4 in Appendix). Thus, the third hypothesis of this study is accepted. Results of this study explained that commissioners could reduce agency conflicts by limiting and monitoring the effectiveness of management or majority owner who can act in their own interest.

\section{Analysis of Audit Committee Effectiveness Influence on Controlling Shareholders and Tax Avoidance Relationship}

Hypothesis 4 (H4) stated that audit committee effectiveness weakens the influence of controlling 
shareholder entrenchment effect against tax avoidance. Results of regression analysis where the variable tax avoidance which was measured by ETR shows effect of relationship as positive and significant, while the results of regression test where tax avoidance variables measured by CETR show negative correlation but not significant (see Table 4 in Appendix). Results of this study proved the fourth hypothesis that audit committee effectiveness weakens negative effect relationships between entrenchment controlling shareholder and corporate tax avoidance. When Audit committee functions more effectively, it prevents controlling shareholders from engaging in tax savings thereby increasing the value of corporate effective tax rates.

Audit committee effectiveness is not significant in relation to controlling shareholders entrenchment effect on the value of CETR of company substance allegedly because of differences in the value of ETR and CETR of the company. Value ETR has the indispensable quality of corporate tax planning which is calculated using permanent differences between policies in the calculation of book income with taxable income. While the value of CETR has fundamentals of tax planning at the same time cash flow planning by managers.

Management policies greatly affect the company's cash flow related to the decision of funds allocation for the company's operations or investments. While the tasks of audit committee related to a review of financial information which led audit committees to tend to focus more on tax management, not the management of cash flow. Therefore, audit committees are more likely to influence ETR of the company.

\section{Analysis of External Quality Audit Influence on Controlling Shareholders and Tax Avoidance Relationship}

Hypothesis 5 (H5) states that external quality audit weakens the influence of controlling shareholder entrenchment effect against acts of tax avoidance.
Regression analysis in this study where variable tax avoidance as measured by ETR showed the effect of relationship as negative and significant, while the results of regression analysis where variable tax avoidance as measured by CETR also shows negative relationship but not significant (see Table 4 in Appendix). This significant difference is likely due to the concentration of auditors and how much the amount of tax imposed by a company which is reflected by value ETR company. While the value of CETR of the company more into the realm of management concentration in determining how much amount of tax paid by the company.

The research initially expected that external quality audit level weakens negative entrenchment effects of controlling shareholders to corporate tax avoidance. But the results of this regression test showed different results with initial prediction effect. This phenomenon occurs because the company's financial statements are audited by Big 4 Accounting Firm that reflects quality audit and add value to the company, and non-controlling shareholders can be confident that their interests are protected. On the other hand, tax avoidance is legal tax savings, which can be justified because it does not violate laws, according to Devano and Rahayu (2006). In this case, it can be justified as absolutely no violation of the law. Thus, controlling shareholders can make tax avoidance and still be able to enjoy tax benefits themselves without having to share it with non-controlling shareholders and it can be covered with an external quality audit by Big 4 Accounting Firm.

\section{Regression Output Control Variable Analysis}

The regression results in this study show variable ROA has significant positive effect on the value of CETR of the company. Variable LEV showed opposite relationship with the initial prediction. Initially, it was predicted that the value of estimated variable LEV will be negatively correlated to effective tax rates (ETR and CETR), but it turns out the regression results showed a positive relationship in accordance with research Sari (2010). 
In the study, Sari (2010) explained that this was partly due to the influence of Circular of Director General of Taxation No. SE-46/PJ, 4/1995. As for the variable size of $\mathrm{PPE}$ and $\mathrm{MB}$, it had a significant negative correlation to value ETR and CETR of the company. The test results are in accordance with the initial predictions; the PPE and MB are positively related to corporate tax avoidance. Consistent with Khuruna and Moser (2009) findings that high growth, in general, has a value lower effective tax rates.

\section{MANAGERIAL IMPLICATIONS}

This study empirically shows that external control mechanisms of corporate governance have not succeeded in protecting the interests of noncontrolling shareholders. Although companies have implemented internal control mechanisms with effective corporate governance, the effect posed on tax avoidance could be different among companies. Therefore, regulators need to pay more attention to corporate governance practices to be able to function effectively as mechanisms of controlling corporate actions. In this way, corporate tax avoidance measures can be minimized in order to benefit the company, company and the society as a whole.

In addition, the regulator is also expected to issue regulations for public companies to disclose ownership structure including pyramid shareholding structure to disclose real shareholders in the company's annual report. This is to give investors information about the company and make controlling shareholders cautious in interpreting mechanisms of corporate governance in the annual report presented by the company as consideration before making their investment decisions.

\section{CONCLUSION}

The results of this study provide evidence that entrenched controlling shareholder has a positive effect on the value of ETR and CETR, which means it will lower tax avoidance. However, these findings do not provide empirical evidence about the influence of family ownership as controlling shareholder on tax avoidance. These results are due to the possibility of a small wedge value which does not motivate family controlling shareholders to engage in tax avoidance.

This study provides evidence that BOCs effectiveness to weaken the relationship between entrenchment effect of controlling shareholders and corporate tax avoidance. Commissioners who do their job effectively will encourage controlling shareholders to increase the value of ETR and CETR of the company. However, audit committee who carry out their duties effectively can only encourage controlling shareholders to increase the company's value of ETR. This study provides evidence that audit committee effectiveness weakens the relationship between controlling shareholders entrenchment effect and corporate tax avoidance. This indicates an increase in ETR value of the company. Contrary to external control mechanisms of corporate governance, the external audit quality by which company financial statements are audited by Big 4 Accounting Firm strengthen the relationship between entrenchment effects of controlling shareholders with corporate tax avoidance measures. The possibility of this phenomenon occurs presumably because there is an opportunity for controlling shareholders to make tax savings that do not violate tax laws and cover up these actions by using Big 4 Accounting Firm to convince non-controlling shareholders that their interests will be protected along with majority shareholders. 
REFERENCES

Badertscher, B.A., Katz, S.P., \& Rego, S.O. (2013). The separation of ownership and control and corporate tax avoidance. Journal of Accounting and Economics 56, 228-250.

Baker, C. R., \& Owsen, D. M. (2014). Increasing the role of auditing in corporate governance. Critical Perspectives on Accounting 13, 783-795.

Chen, S., Chen, X., Cheng, Q., \& Shevlin, T. (2010). Are family firms more tax aggressive than non-family firms? Journal of Financial Economics,95, 41-61.

Claessens, S., Djankov, S., \& Lang, L.H.P. (2000). The separation of ownership and control in East Asia corporation. Journal of Financial Economics 58, 81-112.

Desai, M., \& Dharmapala, D. (2006). Corporate tax avoidance and high-powered incentives. Journal of Financial Economics79, 145-179.

Devano, S., \& Rahayu, S. K. (2006). Perpajakan: Konsep, teori, danisu. Jakarta: Kencana.

Diyanty, V. (2012). Pengaruh Kepemilikan Pengendali Akhir terhadap Transaksi Pihak Berelasi dan Kualitas Laba. Disertasi, Fakultas Ekonomi Program Pasca Sarjana Ilmu Akuntansi Universitas Indonesia Depok.

Effendi, M. A. (2009). The power of good corporate governance: Teori dan implementasi. Jakarta: Salemba Empat.

Fama, E.F., \& Jensen, M.C. (1983). Separation of Ownership and Control. The Journal of Law and Economics, 26(2), 301-325.

Fan, J.P.H., \& Wong, T.J. (2002). Corporate ownership structure and the informativeness of accounting earning in East Asia. Journal of Accounting and Economics 33, 401-425.

Francis, J. R. (2004). What do we know about audit quality. The British Accounting Review 36, 345-368.

Friese, A., Simon, L., \& Mayer, S. (2008). Taxation and corporate governance - the state of the art. Tax and Corporate Governance, Springer Berlin Heidelberg, Volume 3, 357-425.

Hanlon, M., \& Heitzman, S. (2010). A review of tax research. Journal of Accounting and Economics 50, 127-178.

Haryono, S. (2005). Struktur Kepemilikan dalam Bingkai Keagenan. Jurnal Akuntansi \& Bisnis 5, 63-71.

Hermawan, A. A. (2009). Pengaruh Efektifitas Dewan Komisaris dan Komite Audit, Kepemilikan oleh Keluarga dan Peran Monitoring Bank terhadap Kandungan Informasi Laba. Disertasi, Program Studi Ilmu Akuntansi Pasca sarjana Fakultas Ekonomi, Universitas Indonesia, Depok.

Khurana, I. K., \& Moser, W. J. (2009). Institutional ownership and tax aggressiveness. https://papers.ssrn.com/sol3/papers. cfm?abstract_id=1464106.2 Desember 2013 .

Lanis, R., \& Richardson, G. (2011). The effect of board of director composition on corporate tax agressiveness. Journal of Accounting and Public Policy 30, 50-70.

La Porta, R., De Silanes, F.L., \& Shleifer, A. (1999). Corporate ownership around the world. The Journal Of Finance 54, 471-517.

Lo, A.W.Y., Wong, R.M.K., \& Firth, M. (2010). Tax, financial reporting, and tunneling incentives for income shifting: An empirical analysis of the transfer pricing behavior of Chinese-listed companies. American Accounting Association, JATA 32, 1-26.

McGuire, S.T., Wang, D., \& Wilson, R.J. (2011). Dual class ownership and tax avoidance. American Taxation Association Midyear Meeting: JATA Conference.

Richardson, G., Taylor, G., \& Lanis, R. (2013). The impact of board of director oversight characteristics on corporate tax aggressiveness: an empirical analysis. Journal of Accounting and Public Policy, 32(3), 68-88.

Sari, D.K. (2010). Karakteristik kepemilikan perusahaan, corporate governance, dan tindakan pajak agresif. Tesis, Fakultas Ekonomi Program Pasca sarjana Ilmu Akuntansi, Depok.

Siregar, B. (2007). Pengaruh pemisahan hak aliran kas dan hak kontrol terhadap dividen. Simposium Nasional Akuntansi X, $1-44$.

Taylor, G., \& Richardson, G. (2014). Incentives for corporate tax planning and reporting: Empirical evidence from Australia. Journal of Contemporary Accounting \& Economics 10, 1 - 15. 
Appendices

Table 1. Sample Selection Procedures Research

\begin{tabular}{lccccc}
\multicolumn{1}{c}{ Year } & 2010 & 2011 & 2012 & 2013 & Total \\
\hline $\begin{array}{l}\text { Total manufacturing companies listed } \\
\text { on Stock Exchange based IDX Statistics }\end{array}$ & 133 & 139 & 138 & 141 & 551 \\
\hline $\begin{array}{l}\text { Companies not listed on Stock Exchange } \\
\text { during observation in a row }\end{array}$ & $(13)$ & $(13)$ & $(13)$ & $(13)$ & $(52)$ \\
\hline Value ETR and CETR more than one & $(9)$ & $(5)$ & $(7)$ & $(3)$ & $(24)$ \\
\hline Ownership ASTINDO & $(17)$ & $(12)$ & $(20)$ & $(21)$ & $(70)$ \\
\hline Have negative equity & $(11)$ & $(10)$ & $(10)$ & $(11)$ & $(42)$ \\
\hline $\begin{array}{l}\text { Data was not obtained for all study } \\
\text { variables during observation period }\end{array}$ & $(13)$ & $(29)$ & $(18)$ & $(23)$ & $(83)$ \\
\hline Total observation & 70 & 70 & 70 & 70 & 280 \\
\hline
\end{tabular}

Table 2. Results Descriptive Statistics

\begin{tabular}{ccccccc}
\hline Variables & N & Mean & Min. & Median & Max. & Std.Dev. \\
\hline ETR & 280 & 0.25 & 00.00 & 0.25 & 0.996 & 0.14 \\
\hline CETR & 280 & 0.22 & 00.00 & 0.24 & 0.94 & 0.14 \\
\hline WEDGE & 280 & 0.03 & 00.00 & 00.00 & 0.40 & 0.08 \\
\hline FAMILY & 280 & 0.46 & 00.00 & 00.00 & 1.00 & 0.50 \\
\hline EDK & 280 & 0.68 & 0.41 & 0.69 & 0.94 & 0.10 \\
\hline EKA & 280 & 0.71 & 0.36 & 0.73 & 0.94 & 0.11 \\
\hline KAE & 280 & 0.44 & 00.00 & 00.00 & 1.00 & 0.50 \\
\hline ROA & 280 & 0.14 & -0.27 & 0.11 & 1.29 & 0.16 \\
\hline LEV & 280 & 0.09 & 00.00 & 0.01 & 0.69 & 0.14 \\
\hline PPE & 280 & 0.42 & 00.0005 & 0.40 & 1.18 & 0.23 \\
\hline MB & 280 & 3.27 & 0.04 & 1.42 & 45.93 & 5.97 \\
\hline
\end{tabular}

Specification Table:

ETR $=$ effective tax rate; CETR $=$ current tax rate; WEDGE $=$ control rights reduced cash flow rights;

FAMILY = dummy holdings, worth 1 if the company is family as controlling shareholder and 0 otherwise;

$\mathrm{EDK}=$ dummy BOCs effectiveness, worth 1 if BOCs effectiveness index score equal to 34 and 0 otherwise;

$\mathrm{EKA}=$ dummy audit committee effectiveness, worth 1 if audit committee effectiveness index score equal to

22 and 0 otherwise; $\mathrm{KAE}=$ dummy external quality audit, value 1 if the company is audited by Big 4 Accounting

Firm and 0 otherwise; ROA = return on assets; LEV = leverage; PPE = property, plant, and equipment;

$\mathrm{MB}=$ market to book ratio.

\footnotetext{
${ }^{5}$ Controlling shareholder is not categorized as foreign but Indonesia by Kim (2003) in Diyanty (2012) later called ASTINDO
} 
Appendices

Table 3. Results Regression Model 1

\begin{tabular}{|c|c|c|c|c|c|c|c|}
\hline \multicolumn{8}{|c|}{ Model 1} \\
\hline \multirow[t]{2}{*}{ Variables } & \multirow[b]{2}{*}{ Expectations } & \multicolumn{3}{|c|}{ ETR } & \multicolumn{3}{|c|}{ CETR } \\
\hline & & Coef & Prob & & Coef & Prob & \\
\hline $\mathrm{C}$ & & 0.248 & 0.000 & & 0.237 & 0.000 & \\
\hline WEDGE & $\mathrm{H} 1: \quad-$ & 0.374 & 0.003 & $* * *$ & 0.187 & 0.000 & $* * *$ \\
\hline ROA & + & 0.043 & 0.146 & & 0.075 & 0.001 & $* * *$ \\
\hline LEV & - & 0.093 & 0.000 & $* * *$ & 0.140 & 0.002 & $* * *$ \\
\hline PPE & - & -0.049 & 0.000 & $* * *$ & -0.114 & 0.028 & $* *$ \\
\hline MB & - & -0.006 & 0.000 & $* * *$ & -0.005 & 0.013 & $* *$ \\
\hline Adj. R-squared & & & 0.041 & & & 0.049 & \\
\hline F-statistic & & & 288.16 & & & 64.50 & \\
\hline Prob. (F-statistic) & & & 0.000 & & & 0.000 & \\
\hline
\end{tabular}

*** significant at $1 \%$ level $* *$ significant at $5 \%$ level

Specification Table:

ETR $=$ effective tax rate; $\mathrm{CETR}=$ current tax rate; WEDGE $=$ control rights reduced cash flow rights; FAMILY $=$ dummy holdings, worth 1 if the company is family as controlling shareholder and 0 otherwise; $\mathrm{ROA}=$ return on assets; $\mathrm{LEV}=$ leverage; $\mathrm{PPE}=$ property, plant, and equipment; $\mathrm{MB}=$ market to book ratio. 
Appendices

Table 4. Results Regression Model 2

\begin{tabular}{|c|c|c|c|c|c|c|c|c|}
\hline \multicolumn{9}{|c|}{ Model 2} \\
\hline \multirow{2}{*}{ Variables } & \multirow{2}{*}{\multicolumn{2}{|c|}{ Hypothesis }} & \multicolumn{3}{|c|}{ ETR } & \multicolumn{3}{|c|}{ CETR } \\
\hline & & & Coef & Prob & & Coef & Prob & \\
\hline $\mathrm{C}$ & & & 0.270 & 0.000 & & 0.231 & 0.000 & \\
\hline WEDGE & & - & -0.047 & 0.426 & & -0.284 & 0.284 & \\
\hline FAMILY & & - & -0.097 & 0.059 & $* *$ & -0.176 & 0.287 & \\
\hline CWEDGE_FAMILY & $\mathrm{H} 2:$ & - & 0.217 & 0.134 & & 0.146 & 0.377 & \\
\hline EDK & & + & -0.009 & 0.179 & & 0.007 & 0.335 & \\
\hline WEDGE_EDK & H3: & + & 0.231 & 0.061 & $*$ & 0.576 & 0.002 & $* * *$ \\
\hline EKA & & + & 0.019 & 0.174 & & 0.003 & 0.441 & \\
\hline CWEDGE_EKA & $\mathrm{H} 4:$ & + & 0.439 & 0.071 & $*$ & -0.019 & 0.481 & \\
\hline KAE & & + & 0.075 & 0.079 & $*$ & 0.176 & 0.277 & \\
\hline WEDGE_KAE & H5: & + & -0.552 & 0.000 & $* * *$ & -0.058 & 0.406 & \\
\hline ROA & & + & 0.046 & 0.118 & & 0.129 & 0.048 & $* *$ \\
\hline LEV & & - & 0.152 & 0.000 & $* * *$ & 0.023 & 0.366 & \\
\hline PPE & & - & -0.043 & 0.000 & $* * *$ & -0.062 & 0.093 & $*$ \\
\hline MB & & - & -0.007 & 0.000 & $* * *$ & -0.005 & 0.060 & $*$ \\
\hline Adj. R-squared & & & 0.078 & & & 0.091 & & \\
\hline F-statistic & & & 118.15 & & & 22.26 & & \\
\hline Prob. (F-statistic) & & & 0.000 & & & 0.0515 & & \\
\hline
\end{tabular}

*** significant at $1 \%$ level ** significant at $5 \%$ level * significant at $10 \%$ level

Specification Table:

$\mathrm{ETR}=$ effective tax rate CETR $=$ current tax rate WEDGE $=$ control rights reduced cash flow rights; FAMILY = dummy holdings, worth 1 if the company is family as controlling shareholder and 0 otherwise;FAMILY_WEDGE = interaction between FAMILY with WEDGE;EDK =dummy BOCs effectiveness, worth 1 if BOCs effectiveness index score equal to 34 and 0 otherwise; EDK_WEDGE = interaction between EDK with WEDGE;EKA = dummy audit committee effectiveness, worth 1 if audit committee effectiveness index score equal to 22 and 0 otherwise; EKA_WEDGE = interaction between EKA with WEDGE;KAE $=$ dummy external quality audit, value 1 if the company is audited by Big 4 Accounting Firm and 0 otherwise; KAE_WEDGE = interaction between KAE with WEDGE; ROA = return on assets; $\mathrm{LEV}=$ leverage $; \mathrm{PPE}=$ property, plant, and equipment; $\mathrm{MB}=$ market to book ratio. 